\title{
Study of the effect of active coal feed additive on the productivity of meat geese
}

\author{
Vagan Ovsepyan $^{1}$, Natalya Yurina ${ }^{1,2 *}$, Bella Tsipinova ${ }^{1,3}$, Taisia Ustjuzhaninova ${ }^{1,3}$, and \\ Boris Khorin ${ }^{1}$ \\ ${ }^{1}$ Krasnodar Research Centre for Animal Husbandry and Veterinary Medicine, 350055, Krasnodar, \\ Russian Federation \\ ${ }^{2}$ Kuban State Agrarian University named after I.T. Trubilin, 350000, Krasnodar, Russian Federation \\ ${ }^{3}$ Maykop State Technological University, 385000, Maykop, Republic of Adygea, Russian Federation
}

\begin{abstract}
The study of new effective fodder additives produced from byproducts of various industries, including the timber processing industry, is a very relevant issue. Research has been carried out on the study of active coal fodder phytoaddition in feedstuffs for geese fed to meat. According to the results of the scientific experiment, it was established that when introducing the tested active coal fodder additive in the diets of young geese of the Lindov breed, a positive tendency to increase the live weight of poultry, gross and average daily increases was noted, feed costs per $1 \mathrm{~kg}$ of increase in live weight were reduced, slaughter yield increased, and the level of profitability of growing geese per meat increased. Reliable increase of mass of muscular tissue of geese in case of slaughter in the second group by $3.3 \%$ has been established.
\end{abstract}

\section{Introduction}

Issues affecting the field of feeding in the conditions of intensification of the poultry industry are very relevant today. In this regard, an important area of research in the field of poultry feeding is the search for cheaper non-traditional and affordable feed products that will increase poultry productivity and reduce the cost of production [1-5].

Temperate coniferous forests maintain the highest level of biomass among all terrestrial ecosystems and are among the main carbon sinks on Earth [6].

Fodder phytoadditions can have a positive effect on the body of farm animals and birds, affect the main determinants of microbial resistance to drugs, including cell membranes. However, limited distribution, small quantities of raw materials, ecogeographic variations, among other factors such as environmental pollution, climate change and overexploitation of plant resources, are serious obstacles to the full study of potential raw materials for the production of phytoadditions [7].

Unsustainable use of antibiotic feed supplements in livestock, especially as growth stimulants, has become a global problem due to unintentional zoonotic exposure through resistance transmission. Extracts of herbal plants or their secondary metabolites with antimicrobial properties can have similar effects of various antibiotic feed supplements,

\footnotetext{
* Corresponding author: naden8277@mail.ru
} 
preventing the growth of pathogenic microbes and improving health, growth and productivity. Most of the research works related to the use of plant extract-based phytoadditions were primarily focused on the content of phenolic compounds and essential oils, and some were associated with terpenes, saponins, tannins, flavonoids, organic acids, complex carbohydrates and non-protein amino acids. Secondary plant metabolites have a variety of antimicrobial mechanisms, including cell membrane disruption, enzyme inhibition, and prevention of bacterial colonization, and these are only some positive aspects of their use $[8,9]$.

In theory, the use of plant extracts is safer than synthetic antibiotics or drugs, but feed supplements containing them should be evaluated for the primary purpose of testing negative side effects, if any, followed by dosage standardization [10].

The purpose of the research was to study the effect of the active coal feed additive on the productivity of meat geese.

To achieve this goal, the following tasks were identified:

1) study the change in live weight of geese, gross and average daily increases in live weight;

2) determine the costs of feed for the increase of $1 \mathrm{~kg}$ of live weight of poultry;

3) to study influence of the studied additive on slaughter yield, morphological composition of carcasses and development of internal organs;

4) calculate the economic efficiency of growing geese for meat when adding the fodder additive being studied.

\section{Methodology}

To solve the tasks, a research and production experiment was carried out on geese of the meat Linda breed in the conditions of the ethno-complex "Kuban Khutorok" in Yeisk (KFH Derenchenko A.V.), Krasnodar Territory. From geese of daily age, 4 groups of 36 heads each were formed. According to the test scheme, 1 group (control) received the basic diet without supplements for the entire growing period. The feed stock for the second group of geese included $0.06 \%$ by weight of the feed of the active coal feed additive.

The scheme of studies on geese is given in Table 1.

Table 1. Test flow chart, $\mathrm{n}=36$

\begin{tabular}{|c|c|}
\hline Group & Feeding Features \\
\hline $\begin{array}{c}1 \\
\text { (control) }\end{array}$ & Main diet \\
\hline 2 (test) & $\begin{array}{c}\text { Main diet }+0,06 \% \text { by weight of fodder of active coal } \\
\text { fodder additive }\end{array}$ \\
\hline
\end{tabular}

The experiment was conducted according to the generally accepted poultry methodology (All-Russian Poultry Research and Technology Institute, 2013). The bird of all groups was kept under the same conditions, with free access to feed and water. The experiment lasted from 1 to 77 days of growing geese.

The composition and nutritional value of the feed for geese at different age periods is shown in Table 2. 
Table 2. Composition and nutritional content of diets for geese, (\%)

\begin{tabular}{|c|c|c|c|}
\hline \multirow{2}{*}{ Indicators } & \multicolumn{3}{|c|}{ Growing period } \\
\cline { 2 - 4 } & $\begin{array}{c}\text { start } \\
\mathbf{1 - 1 4} \text { days }\end{array}$ & $\begin{array}{c}\text { growth } \\
\mathbf{1 5 - 4 2} \text { day }\end{array}$ & $\begin{array}{c}\text { finish } \\
\mathbf{4 3 - 7 7} \text { days }\end{array}$ \\
\hline Corn & 27,0 & - & - \\
\hline Wheat & 36,3 & 45,0 & 14,9 \\
\hline Barley & - & 23,0 & 47,0 \\
\hline Wheat bran & - & - & 9,4 \\
\hline $\begin{array}{c}\text { Sunflower } \\
\text { extraction cake }\end{array}$ & 14,0 & 6,5 & 2,0 \\
\hline Fodder yeast & 9,0 & 7,0 & 4,0 \\
\hline $\begin{array}{c}\text { Meat and bone } \\
\text { flour }\end{array}$ & 3,0 & 2,0 & 1,5 \\
\hline Herbal flour & 5,3 & 10,8 & 15,0 \\
\hline Limestone & 2,0 & 2,2 & 2,7 \\
\hline Table salt & 0,4 & 0,5 & 0,5 \\
\hline Sunflower oil & 2,0 & 2,0 & 2,0 \\
\hline Premix & 1,0 & 1,0 & 1,0 \\
\hline \multicolumn{2}{|c|}{ Feed Nutritionality } \\
\hline $\begin{array}{c}\text { Exchange } \\
\text { energy, kcal }\end{array}$ & 290,1 & 278,0 & 270,0 \\
\hline Crude fat & 3,29 & 5,22 & 4,85 \\
\hline Raw fiber & 6,0 & 6,5 & 6,73 \\
\hline Crude protein & 20,6 & 19,2 & 17,5 \\
\hline Calcium & 1,30 & 1,7 & 2,3 \\
\hline Phosphorus & 0,81 & 0,7 & 0,8 \\
\hline
\end{tabular}

Diets for geese in the scientific and production experience were balanced in all nutrients and corresponded to the needs of poultry in all periods of cultivation.

Active coal fodder additive is a phytoaddition based on carbonized biomass of forest (coniferous greens) and coniferous extract produced by LLC STC "Khiminvest" (Nizhny Novgorod, the Russian Federation).

The dynamics of live mass were recorded by individual weighing of geese on electronic scales (periodically). Gross and average daily increases in live weight of geese were calculated based on data obtained as a result of periodic weighing.

Feed costs per $1 \mathrm{~kg}$ of live weight gain were calculated taking into account these changes in live weight and the amount of feed consumed.

At the end of the experiment, a control slaughter of 6 heads ( 3 males and

3 females) from each group, in order to study the slaughter yield, morphological composition of carcasses and the development of the internal organs of the bird. Economic efficiency was calculated according to economic indicators provided by the economy.

Biometric data were calculated in the Microsoft Excel program according to N.A. Plokhinsky (1969), the differences were considered reliable at $\mathrm{p}<0.05$; $\mathrm{p}<0.01$; $\mathrm{p}<0.001$.

\section{Results and discussion}

The changes in live weight of the poultry are shown in Table 3. 
Table 3. Dynamics of live mass of geese, $M \pm m$, g, $(n=36)$

\begin{tabular}{|c|c|c|}
\hline \multirow{2}{*}{ Age, days } & $\mathbf{2}$ & Group \\
\cline { 2 - 3 } & $\mathbf{1}$ & $\mathbf{2}$ \\
\hline 1 & $85,0 \pm 0,60$ & $85,3 \pm 0,66$ \\
\hline 30 & $1321,0 \pm 22,74$ & $1324,1 \pm 25,77$ \\
\hline \% to control & 100,0 & 100,2 \\
\hline 77 & $3290,0 \pm 63,01$ & $3332,5 \pm 54,94$ \\
\hline \% to control & 100,0 & 101,3 \\
\hline $\begin{array}{c}\text { Average daily } \\
\text { increase, } g\end{array}$ & 41,60 & 42,20 \\
\hline
\end{tabular}

At the beginning of the experiment, the live weight of the geese was almost the same. After 30 days of cultivation in the experimental groups, there was a tendency to increase live weight, in comparison with control. As a result of periodic weighing of poultry, it was found that in the indicator of live weight of geese of the second group there was a tendency to increase it by $1.3 \%$. Gross growth of live weight of geese during the fattening period of 1-30 days was $1236.0 \mathrm{~g}$ in the control group, $1238.8 \mathrm{~g}$ in the experimental group, 1969.0 and $2008.4 \mathrm{~g}$ in the period of 31-77 days, respectively, and 3205.0 and $3247.2 \mathrm{~g}$ in the whole fattening period, respectively, by groups.

According to estimated data, in the period of 1-30 days, the average daily increase in the live weight of geese in the first and second groups was almost the same. The use of the active coal additive in mixed feed for meat geese in the second fattening period (31-77 days) contributed to an increase in average daily increases in the experimental group by $2.1 \%$. The calculation of the average daily increases for the whole period of the experiment (1-77 days) showed that this indicator in the experimental group was higher than in the control by 1.4 , \%.

For the entire period of experience, the safety of the livestock was $100 \%$, in all groups, which indicates a good zootechnical background of research.

The results of accounting of consumed fodders and their costs per $1 \mathrm{~kg}$ of live weight increase are presented in Table 4.

Table 4. Feed costs per $1 \mathrm{~kg}$ of live weight gain, $\mathrm{kg}$

\begin{tabular}{|c|c|c|}
\hline \multirow{2}{*}{ Indicators } & \multicolumn{2}{|c|}{ Group } \\
\cline { 2 - 3 } & 1 & $\mathbf{2}$ \\
\hline $\begin{array}{c}\text { Consumed feed } \\
\text { for the whole } \\
\text { experience, } \mathrm{kg}\end{array}$ & 12,40 & 12,20 \\
\hline \% to control & 100,00 & 98,40 \\
\hline $\begin{array}{c}\text { Feed costs per } 1 \\
\mathrm{~kg} \text { increase, } \mathrm{kg}\end{array}$ & 3,87 & 3,76 \\
\hline
\end{tabular}

As a result of accounting for consumed feed, it was found that less feed was consumed in the experimental group, in comparison with the control, by $1.6 \%$.

The use of active coal feed additive in an amount of $0.06 \%$ by weight of feed in the second group reduced feed consumption per $1 \mathrm{~kg}$ of live weight gain by $2.9 \%$ compared to the control group.

At the end of the experiment, a control slaughter of geese of 6 heads from each group (3 males and 3 females) was carried out (Table 5). 
Table 5. Results of control slaughter $(n=6)$

\begin{tabular}{|c|c|c|}
\hline \multirow{2}{*}{ Indicators } & \multicolumn{2}{|c|}{ Group } \\
\hline & 1 & 2 \\
\hline $\begin{array}{l}\text { Pre-slaughter } \\
\text { mass, g }\end{array}$ & $3300,0 \pm 12,9$ & $3319,2 \pm 12,0$ \\
\hline $\begin{array}{c}\text { Mass of the } \\
\text { ripped carcass, } \\
\mathrm{g}\end{array}$ & $1956,9 \pm 13,3$ & $1991,5 \pm 7,7$ \\
\hline $\begin{array}{c}\text { Slaughter yield, } \\
\%\end{array}$ & 59,3 & 60,0 \\
\hline \multicolumn{3}{|c|}{ Morphological composition of carcasses } \\
\hline Muscle mass, g & $1020,5 \pm 14,0$ & $1105,3 \pm 18,1^{* * *}$ \\
\hline$\%$ yield & 52,15 & 55,50 \\
\hline Fat, $g$ & $47,00 \pm 3,06$ & $46,80 \pm 1,72$ \\
\hline$\%$ yield & 2,40 & 2,35 \\
\hline \multicolumn{3}{|c|}{ Internal organs } \\
\hline Heart, g & $23,10 \pm 1,66$ & $26,55 \pm 1,39$ \\
\hline $\begin{array}{c}\text { \% to pre- } \\
\text { slaughter mass }\end{array}$ & 0,70 & 0,80 \\
\hline Liver, g & $62,70 \pm 1,83$ & $59,74 \pm 1,30$ \\
\hline $\begin{array}{c}\% \text { to pre- } \\
\text { slaughter mass }\end{array}$ & 1,90 & 1,80 \\
\hline $\begin{array}{l}\text { Glandular } \\
\text { stomach, g }\end{array}$ & $16,50 \pm$ & $13,28 \pm$ \\
\hline $\begin{array}{c}\text { \% to pre- } \\
\text { slaughter mass }\end{array}$ & 0,50 & 0,40 \\
\hline Gallbladder, g & $4,29 \pm$ & $4,31 \pm$ \\
\hline $\begin{array}{c}\text { \% to pre- } \\
\text { slaughter mass }\end{array}$ & 0,13 & 0,13 \\
\hline Intestine, $\mathrm{g}$ & $214,50 \pm$ & $205,79 \pm$ \\
\hline $\begin{array}{c}\% \text { to pre- } \\
\text { slaughter mass }\end{array}$ & 6,50 & 6,20 \\
\hline $\begin{array}{c}\text { Muscular } \\
\text { stomach, g }\end{array}$ & $125,40 \pm$ & $129,45 \pm$ \\
\hline $\begin{array}{c}\text { \% to pre- } \\
\text { slaughter mass }\end{array}$ & 3,80 & 3,90 \\
\hline $\begin{array}{c}\text { Intestine length, } \\
\mathrm{cm}\end{array}$ & $246,80 \pm$ & $234,50 \pm$ \\
\hline$\%$ to control & 100,00 & 95,02 \\
\hline
\end{tabular}

According to the results of control slaughter, it was found that the use of a feed additive in the experimental group contributed to an increase in the slaughter yield of geese carcasses by $0.7 \%$.

The meat yield percentage increased by $3.3 \%$ in the test group compared to the control group $(\mathrm{p}<0.001)$.

When feeding the goose with active coal feed additive, there was a tendency to reduce the length of the intestine and blind processes as part of full-breeding feed.

The remaining data on the mass of internal organs do not reveal any trend, nor is the negative effect of the feed additive established. The internal organs of geese of all groups were within the physiological norm for this species of bird and their age.

At the end of the scientific experiment, the economic efficiency of growing geese using the additive studied was calculated (Table 6). 
Table 6. Economic efficiency of geese cultivation (1 head) in the test

\begin{tabular}{|c|c|c|}
\hline \multirow{2}{*}{ Indicators } & \multicolumn{2}{|c|}{ Group } \\
\cline { 2 - 3 } & 3205,00 & $\mathbf{2}$ \\
\hline Gross growth, g & 240,00 & 3247,20 \\
\hline $\begin{array}{c}\text { Sale cost 1 kg } \\
\text { live mass, } \\
\text { rubles }\end{array}$ & 769,20 & 240,00 \\
\hline $\begin{array}{c}\text { Cost of gross } \\
\text { products, rubles }\end{array}$ & 12,40 & 779,33 \\
\hline $\begin{array}{c}\text { Consumed food } \\
\text { per 1 head, kg }\end{array}$ & 272,80 & 12,20 \\
\hline $\begin{array}{c}\text { Cost of } \\
\text { consumed feed, } \\
\text { rubles }\end{array}$ & - & 269,28 \\
\hline $\begin{array}{c}\text { Cost of feed } \\
\text { additive, rubles }\end{array}$ & 198,00 & 0,88 \\
\hline $\begin{array}{c}\text { Production } \\
\text { costs, rubles }\end{array}$ & 571,20 & 194,48 \\
\hline $\begin{array}{c}\text { Profit received, } \\
\text { rubles }\end{array}$ & - & 584,85 \\
\hline $\begin{array}{c}\text { Additional } \\
\text { received } \\
\text { profit, rubles }\end{array}$ & 74,26 & 13,65 \\
\hline $\begin{array}{c}\text { Profitability } \\
\text { level, \% }\end{array}$ & & 75,04 \\
\hline
\end{tabular}

From the calculated data, it can be seen that the use of the active coal feed additive in the composition of feed feedstuffs for geese grown for meat in the experimental group contributed to a decrease in the cost of consumed feeds by $1.3 \%$, compared with the control.

Production costs decreased by $1.8 \%$ in the second group.

The level of profitability of growing geese using a feed additive increased by $0.8 \%$ in the experimental group, in comparison with control.

\section{Conclusions}

According to the results of the scientific experiment, it was established that when feeding an active coal feed additive in the diets of geese fed to meat, a positive tendency is observed to increase the live weight of poultry, gross and average daily increases, feed costs per $1 \mathrm{~kg}$ of live weight increase are reduced, slaughter yield increases, and the level of profitability of growing geese per meat increases. Reliable increase of mass of muscular tissue of geese in case of slaughter in the second group is established.

\section{References}

1. Z. Lu, A. Thanabalan, H. Leung, R. Akbari Moghaddam Kakhki, R. Patterson, E. G. Kiarie, Poultry Science, 98, 6411-6421 (2019) doi: 10.3382/ps/pez479

2. W. Siegert, T. Zuber, V. Sommerfeld, J. Krieg, D. Feuerstein, U. Kurrle, M. Rodehutscord, Poultry Science, 98, 5700-5713 (2019) doi: 10.3382/ps/pez355

3. Yefei Zhou, Shanguo Mao, Meixian Zhou, Poultry Science, 98, 2790-2799 (2019) doi: 10.3382/ps/pez071 
4. Shu-Biao Wu, Robert A. Swick, Jean Noblet, Nicholas Rodgers, David Cadogan, Mingan Choct, Poultry Science, 98, 1222-1234 (2019) doi: 10.3382/ps/pey442

5. O.O. Babatunde, A.J. Cowieson, J.W. Wilson, O. Adeola, Poultry Science, 98, 67426750 (2019) doi.org/10.3382/ps/pez390

6. R. Starke, R. L. Mondéjar, Z.R. Human et al., Soil Biology and Biochemistry, 155, 108170 (2021)

7. P. Tiwari, T. Khare, V. Shriram, H. Bae, V. Kumar, Biotechnology Advances, 48, 107729 (2021) https://doi.org/10.1016/j.biotechadv.2021.107729

8. P. R. K. Reddy, M.M.M.Y. Elghandour, A.Z.M. Salem, D. Yasaswini, P. P. R. Reddy, A. N. Reddy, I. Hyder, Animal Feed Science and Technology, 264, 114469 (2020)

9. Ch M. Franz, K. H. C. Baser, I. Hahn-Ramssl, Feed Additives Aromatic Plants and Herbs in Animal Nutrition and Health, 35-56 (2020) https://doi.org/10.1016/B978-012-814700-9.00003-0

10. M.M.M.Y. Elghandour, P.R.K. Reddy, A.Z.M. Salem, P.P.R. Reddy, I. Hyder, A. Barbabosa-Pliegoa, D. Yasaswinid, Journal of Equine Veterinary Science, 69, 66-77 (2018) https://doi.org/10.1016/j.jevs.2018.06.004 